\title{
Diagnosztikus szívkatéterezés. Mindennapos beavatkozás, nem mindennapi esemény
}

\author{
Sasi Viktor, Havasi Kálmán, Szántó Gyula, Forster Tamás, Nemes Attila, Ungi Imre
}

Szegedi Tudományegyetem, Általános Orvostudományi Kar, II. sz. Belgyógyászati Klinika és Kardiológiai Központ, Szeged

Levelezési cím:

Dr. Sasi Viktor, 6725 Szeged, Semmelweis utca 8., e-mail: sasiviktor@gmail.com

A szignifikáns aortastenosissal diagnosztizált beteg aorta mübillentyü-beültetést megelőző kivizsgálás miatt került felvételre, klinikánkra. Klinikai echokardiográfiás vizsgálata a meszes aortabillentyü felett $107 \mathrm{Hgmm}$-es csúcs-, 60 Hgmm-es átlaggrádienst igazolt, a számított billentyüfelszín $0,9 \mathrm{~cm}^{2}$-nek adódott. A tervezett szívműtétet megelőzőleg koronarográfiát indikáltunk. A szívkatéterezést a klinikánkon rutinszerüen jobb arteria radialis behatolásból, $5 \mathrm{~F}$ diagnosztikus Judkins bal (JL) és jobb (JR) katéterrel végeztük. Az eseménymentes szúrást, felhatolást követően a bal diagnosztika után a JR-katéterrel az aorta ascendensben történt hosszas manipuláció kapcsán már felvezető dróttal feloldhatatlan „csomó” képződését láttuk. A diagnosztikus katétert megpróbáltuk eltávolítani így is, de a felkarban a konglomerátum átmérője és jelentős spazmus miatt elakadtunk. Több innovatív megoldási lehetőség közül az ellenoldal felöl ipsilaterális behatolásból végzett lasszózás és mindkét behatolási kapun keresztül erős húzás és az ellenoldal felöl óramutató járásával ellentétes csavarás végül sikerhez vezetett. A lasszó elengedése után mindkét irányból sikeresen eltávolítottuk a katétereket (lasszó, feszítéses-csavarós módszer). A felkar, alkar ellenoldal felöl végzett angiográfiája, illetve az alkar artériáinak ultrahangvizsgálata intakt artériás keringést igazolt.

Kulcsszavak: aortastenosis, szívkatéterezés, arteria radialis, endovaszkuláris lasszó

Diagnostic coronary angiography - routine procedure, unexpected event

A patient diagnosed with significant aortic valve stenosis was admitted to the University Clinic for mandatory examinations prior to surgical aortic valve replacement. Echocardiography confirmed the initial diagnosis. There was $107 \mathrm{mmHg}$ peak and $60 \mathrm{mmHg}$ mean gradient over the aortic valve and aortic valve area was $0.9 \mathrm{~cm}^{2}$. Coronary angiography was planned. Coronary angiography was performed with $5 \mathrm{~F}$ diagnostic Judkins left and right catheter from the radial approach as a standard at our institute. After uneventful puncture, initial left coronary system angiography was carried out without any difficulty. During long manipulation with the JR catheter in the right coronary cusp we could visualize a "knob" formation in the ascending aorta on the catheter. This knob could not be unraveled with wires. We tried to extract the ruined diagnostic catheter with a three dimensional kinking on it, but due to its size and vasospasm it was impossible. We tried different innovative tricks, but at the end we got close to the stuck catheter from the opposite direction with a gooseneck snare, grabbed it, pulled it into the brachial artery and with stretching rotation and twisting the knob unraveled. After letting go of the catheter it could easily be retracted from the initial puncture site. The angiography of the right arm showed no dissection or closure of any vessel involved during the procedure. Follow up ultrasounds have shown the same result during the course of institutional stay.

Kulcsszavak: aortic valve stenosis, coronary angiography, radial artery, endovascular snare 


\section{Bevezetés}

A szívkatéterezés fejlődése során mérföldkőnek számított a radialis behatolásból elsőként elvégzett diagnosztikus vizsgálat 1989-ben (1). Ezt követően 1993-ban Kiemeneij már néhány beteg koronária-angioplasztikájának eredményeit közölte a radialis behatolás felöl (2). Vorobcsuk metaanalízisében ST-elevációs miokardiális infarktus (STEMI) intervenciós kardiológiai ellátása során a radialis behatolásból végzett intervenciók vérzéses szövődményeinek szignifikáns csökkenését igazolták több ezer beteget felölelő publikációjukban (3). Azt mondhatjuk, hogy az utóbbi negyed évszázad a radialis behatolásból történő diagnosztikus és intervenciós beavatkozások jelentős térnyerését hozta, még STEMI ellátása során is. Napjainkban Magyarországon a radialis behatolásból végzett szívkatéterezések és intervenciók aránya $90 \%$-ra tehető. A diagnosztikus szívkatéterezés során észlelt szövődmények és problémák előfordulásának aránya nem jelentős, de az időnként előforduló, katéterrel kapcsolatos problémák megoldása fejtörést okozhat.

\section{Esetismertetés}

A 76 éves férfi beteg anamnézisében hipertónia, 2-es típusú diabetes mellitus, obesitas szerepeltek. Effort angina és dyspnoe miatt indult kivizsgálása. Elektrokardiogram (EKG) regisztrátumon sinusritmust észleltünk normofrekvenciával és balkamra-hipertrófiára jellemző képet. Klinikai echokardiográfiás vizsgálattal tágabb pitvarok, normális tágasságú bal és jobb kamra, jó bal- és jobbkamra-funkció igazolódott regionális falmozgászavar nélkül. A meszes aortastenosis vizsgálata 107 Hgmm-es csúcs-, $60 \mathrm{Hgmm}$-es átlaggrádienst igazolt, a számított billentyüfelszín $0,9 \mathrm{~cm}^{2}$-nek adódott. Ezt követően koronarográfiát indikáltunk. A szívkatéterezést a klinikánkon rutinszerủen jobb arteria radialis behatolásból végeztük $5 \mathrm{~F}$ hüvelyen keresztül. Az eseménymentes szúrást és felhatolást követően megtörtént a bal koronáriarendszer angiográfiás vizsgálata $5 \mathrm{~F}$ diagnosztikus JL4 katéterrel (Terumo, Japán), amely nem szignifikáns elülső leszálló ág (LAD) szűkületet igazolt (1. ábra, panel $A, B$ ). Ezt követően a JR4 (Terumo, Japan) diagnosztikus katéterrel az aorta ascendensben történt

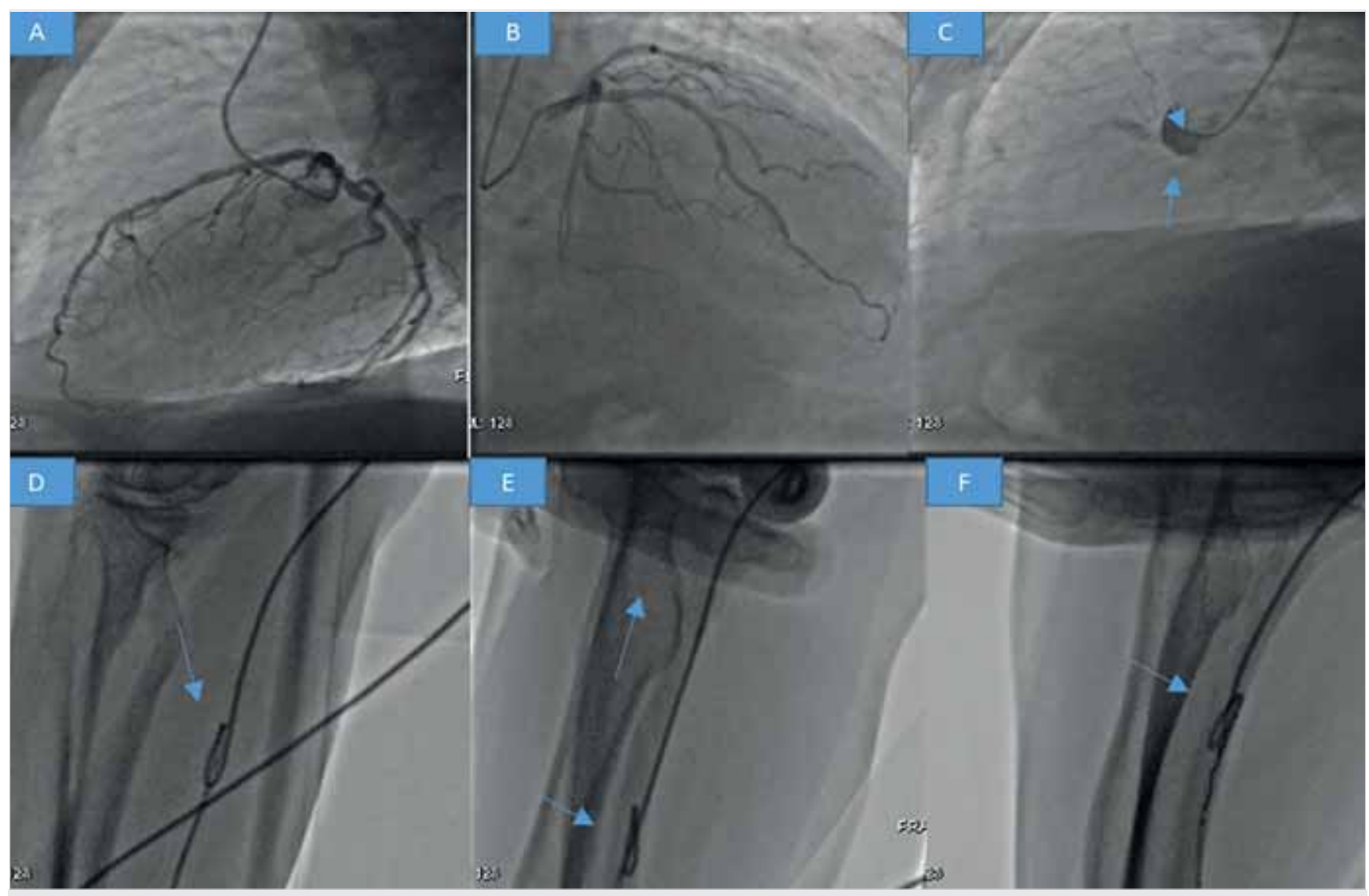

1. ÁBRA. Panel A: bal koronáriarendszer angiográfia laterális nézet. Szignifikáns szűkület nem ábrázolódik. Panel B: bal koronáriarendszer angiográfia, RAO 20, CRA 40 nézet. Szignifikáns szűkület nem ábrázolódik. Panel C: jobb koronária szelektív angiográfiája sikertelen (nyíl). Panel D: a sérült diagnosztikus 5F JR4 katéter eltávolítási kísérlete, de spazmus, helyhiány miatt elakadás áll fenn (nyilak). Panel E: a csontos alaphoz történik a katéter disztális részének szorítása, de a csomó nem oldódik (nyilak). Panel F: intervencióhoz használt vezetődrótok alkalmazása a megtöretés kiegyenesítésére (BHW, Whisper ES) sikertelen (nyíl) 
hosszas manipuláció kapcsán már Teflonbevonatos dróttal feloldhatatlan többes megtöretést láttunk a katéteren, amely „csomót” imitált (1. ábra, panel C). A diagnosztikus katétert megpróbáltuk eltávolítani így is, de az alkar felé haladva az átmérő és jelentős vazospazmus miatt elakadtunk (1. ábra, panel D). Megpróbáltuk az átvilágítás alatt a csontos alaphoz szorítani a katéter végét, közben húzni a katétert, de ez sem hozott megoldást (1. ábra, panel E). Ezt követően koronária-intervencióhoz használatos vezetődrótokat próbáltunk átjuttatni a sérült, mostanra deformált katéteren (BHW, Whisper ES, Abbott Vascular, Usa) sikertelenül (1. ábra, panel F). Egyértelmúvé vált, hogy a tervezett behatolási kapun keresztül képtelenek vagyunk a sérült katétert eltávolítani az alkar artériáinak sérülése nélkül. Ezt követően $6 \mathrm{~F}$ jobb arteria femoralis behatoláson keresztül a jobb brachialis artériába Multipurpose 6F guiding katétert vittünk (Medtronic, Usa), majd OneSnare (Merit Medical, Usa) lasszóval sikeresen elkaptuk a destruált JR-katéter disztális végét. Négykezes megoldást alkalmaztunk, két kéz a femoralis behatolás felé húzta a katétereket, közben az óramutató járásával ellentétes irányban végeztünk csavaró mozgást, az ellenoldali két kéz pedig a radialis behatolás felé húzta a sérült katétert, amely egyszer engedett, a „csomó” elnyúlt és oldódni látszott (2. ábra, panel $A, B, C, D$ ). A lasszóval elengedtük a diagnosztikus katétert, amelyet a radialis behatolás felé eltávolítottunk a szúrási hüvelyen keresztül (2. ábra, panel $E, F)$. Ezt követően angiográfiát végeztünk a kar artériáiról, de érsérülést nem láttunk (3. ábra, panel $A$, $B, C)$. Ezt az intézeti észlelés során végzett Duplex ultrahangvizsgálatok is megerősítették (3. ábra, panel D). Befejezésként femoralis behatolásból elvégeztük a jobb koronária szelektív angiográfiáját (3. ábra, panel E).

\section{Megbeszélés}

Az utolsó negyedszázad a radialis behatolásból végzett diagnosztikus és kuratív szívkatéterezés diadal-
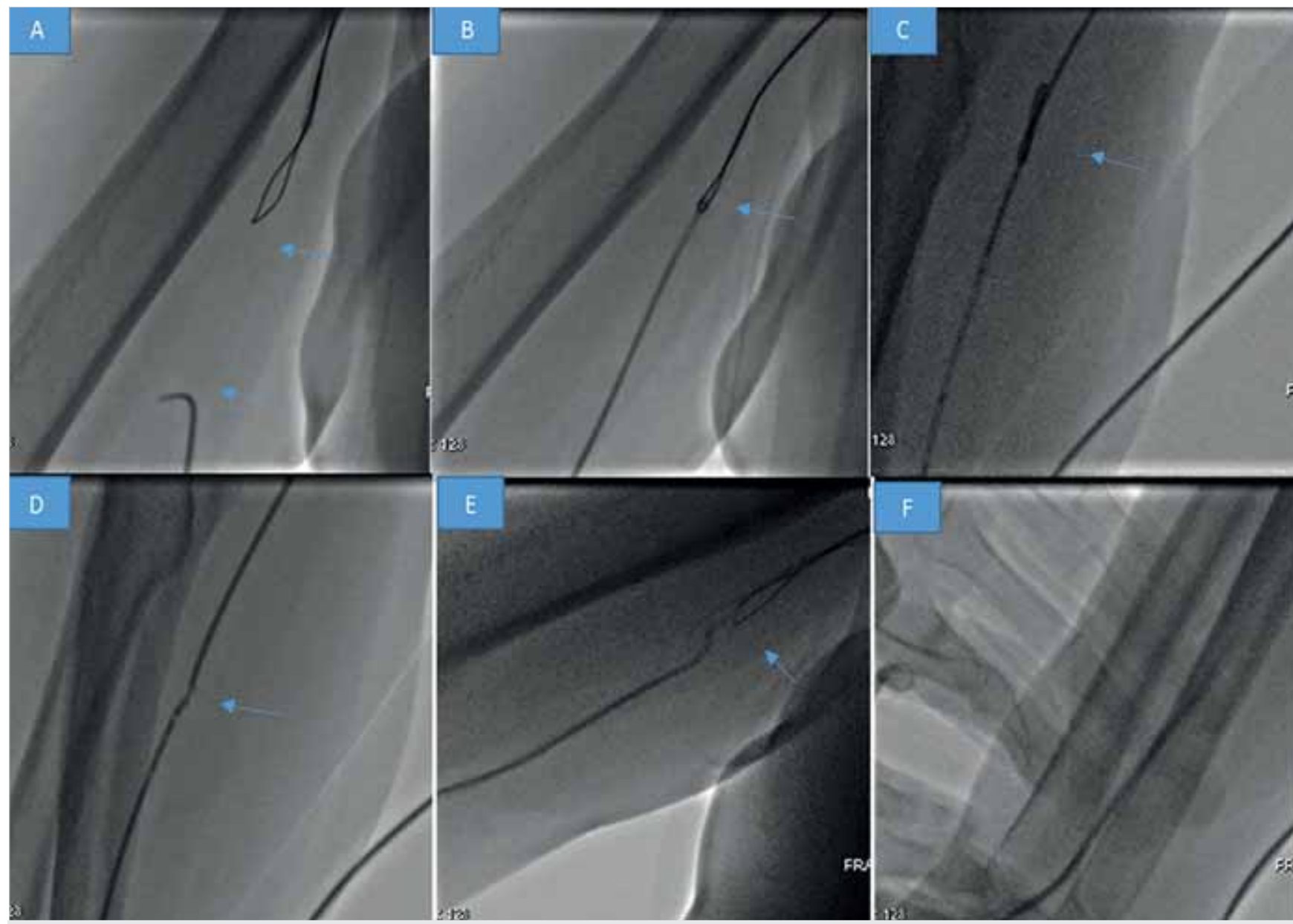

2. ÁBRA. Panel A, B: multipurpose 6F (Medtronic, Usa) katétert vezetünk a jobb arteria femoralis behatolás felől a brachialis artériába, majd Onesnare (Merit Medical, Usa) lasszóval elkapjuk a sérült katéter disztális részét (nyilak). Panel C, D: „négykezes” megoldással két kéz a femoralis behatolás felé húzza a katétereket, közben az óramutató járásával ellentétes irányban végzünk csavaró mozgást, az eredeti behatolás felőli másik két kéz pedig a radialis behatolás felé húzza a sérült katétert, amely enged (nyilak). Panel E: a lasszó elengedi a katéter disztális részét (nyíl). Panel F: eltávolítjuk a radialis behatoláson keresztül a csomómentesített katétert 


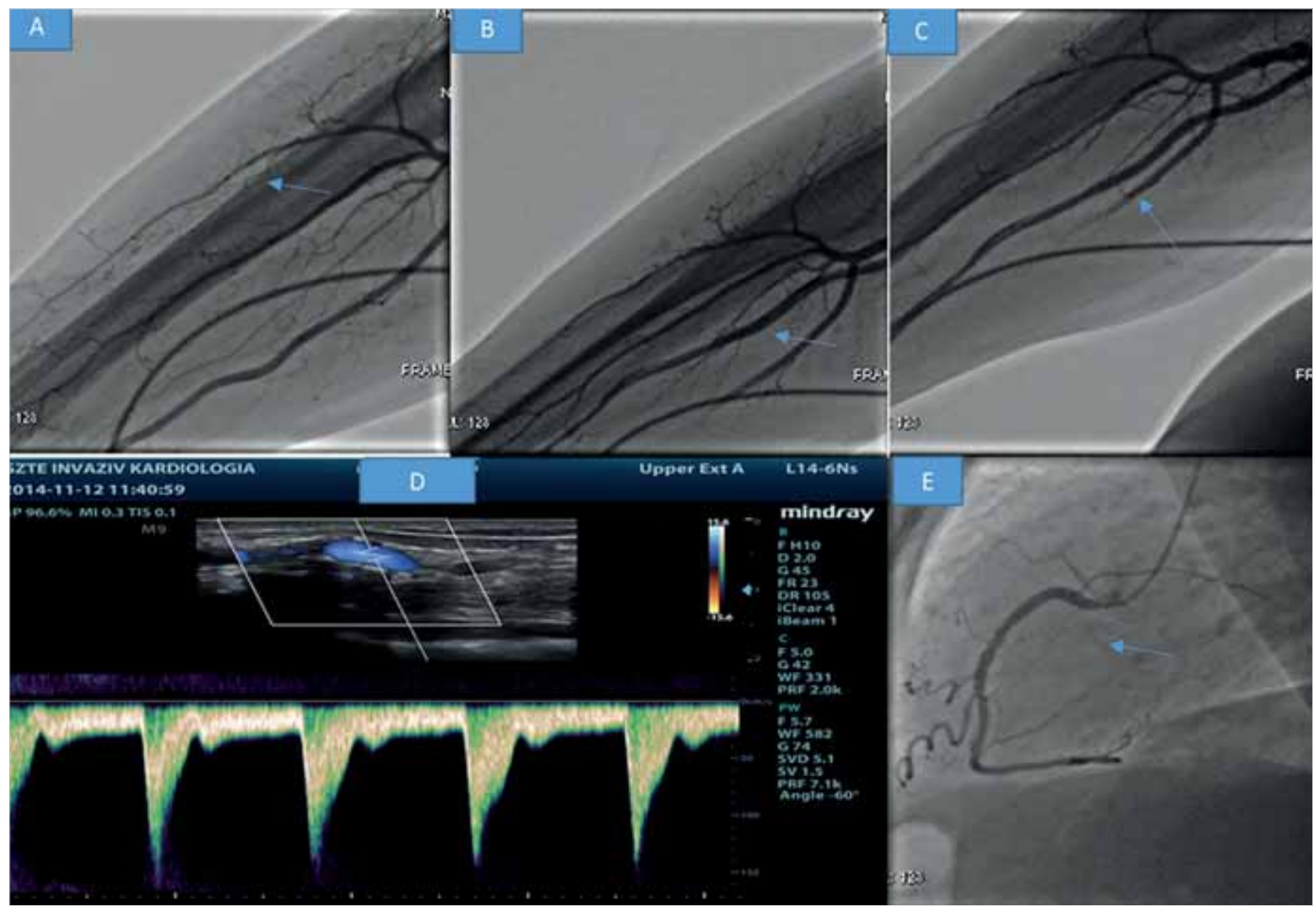

3. ÁBRA. Panel A, B, C: Az arteria brachialis felöl végzett artériás angiográfia nem mutat érsérülést, vagy elzáródást (nyilak). Panel D: duplex ultrahang az arteria radialis intakt voltát igazolja. Panel E: a szelektív jobb koronária-angiográfia nem igazol érdemi szűkületet (nyíl)

menete. A Campeau által közölt első diagnosztikus beavatkozást követően észlelt fejlődés töretlen (1). Kiemeneij 25 éve közölte első tapasztalatait koronária-intervenció elvégzése kapcsán radialis behatolást alkalmazva (2). Vorobcsuk által végzett metaanalízis több mint 5000 beteg adatait dolgozta fel STEMI esetén és arra a következtetésre jutott, hogy a behatolási kaput érintő vérzéses szövődmények $70 \%$-kal csökkentek, az összesített mortalitás és nagy kardiovaszkuláris adverz események előfordulásának csökkenése erős szignifikanciát mutatott a femoralis behatoláshoz képest (3). Bertrand által készített felmérés 75 ország invazív kardiológusainak radiális beavatkozással kapcsolatos szokásait vizsgálta. 2010-re világszerte rutinszerüen alkalmazták a radialis behatolásból végzett diagnosztikus és kuratív kardiovaszkuláris beavatkozásokat és ennek további emelkedését véleményezték a megkérdezett orvosok (4). A radialis behatolásból végzett beavatkozások számának emelkedésével a potenciálisan előforduló, de elhárítható szövődmények emelkedése is együtt jár. A katéterek több lokalizációban való megtöretése és háromdimenziós konglomerátum képződése lehet a leggyakoribb probléma a katéterezés során.
Esetünkben is ez történt a hosszas manipulációt követően a diagnosztikus katéterrel. Irodalmi adatok és saját tapasztalatok alapján a katéter belső lumenének elvesztése és külső integritásának sérülése a legtöbb esetben a lumenbe vezetett vezetődrót (0.035., 0.014. inch) segítségével még orvosolható. Amennyiben többes megtöretések és hajtűkanyarok alakulnak ki, más megoldásokat kell keresni, hogy az érintett artériák sérülését elkerüljük. A csontos alaphoz való katéterleszorítás, közben a katéter erőteljes húzása opció lehet, de sem ez, sem pedig vérnyomásmérő mandzsettájának felfújása nem feltétlenül tud megfelelő kompressziót biztosítani, mint ahogy ez a mi esetünkben is történt (5, 6, 7). 2012-ben Kim és Waked publikációiban az ellenkező oldal felől végzett lasszó alkalmazásával sikerült a katéter megragadása, a megtöretés feloldása és az első behatolási kapun történő eltávolítása. Esetünkben a megtört diagnosztikus katéter okozta háromdimenziós konglomerátumot csak az ellenoldal felöl lehetett megközelíteni és végül sikerült megragadni, majd, hogy elkerüljük a radialis artéria sérülését, ezt a több helyet biztosító brachialis artériába húzni. Itt a négykezes technikával sikerült a megtört katétert ellenkező irányú 
húzás-csavarással kiegyenesíteni. Ezt követően, már elengedve a katétert, az elsődleges punkciós hüvelyen keresztül el tudtuk azt távolítani. Az alkar artériáinak angiográfiája a sikeres lasszóalkalmazás miatt nem mutatott eltérést, így további ellátásra nem volt szükség. Amennyiben ezen módszer sem járt volna eredménnyel az Aminian által 2015-ben közölt "sheathless” guiding katéteres kiegyenesítés is szóba jöhetett volna, de ez esetben az esetleges vaszkuláris komplikáció esélye fokozottabb.

\section{Következtetések}

A radialis behatolásból végzett diagnosztikus vagy kuratív beavatkozások mára rutin feladatot képeznek. Az anatómiai helyzet felmérése és kellő óvatosság a katétert érintő potenciális szövődmények számát minimalizálhatja. Amennyiben a katéter sérülése, megtöretése, vagy „csomóképződés” lép fel, az innovatív megoldások keresése többet ér a puszta erőnél. Esetbemutatásunkkal azt bizonyítottuk, hogy a katétert érintő megtöretések a katéteres laboratóriumokban elérhető eszközök (pl. lasszó, sheathless katéter) alkalmazásával megoldást, megnyugvást hozhat a „rutin” beavatkozás végére.
Irodalom

1. Campeau L. Percutaneous radial artery approach for coronary angiography. Catheterization and Cardiovascular Diagnosis 1989; 16(1): 3-7. doi: 10.1002/ccd.1810160103

2. Kiemeneij F, Laarman GJ, et al. Percutaneous transradial artery approach for coronary stent implantation. Cathet Cardiovasc Diagn 1993 Oct; 30(2): 173-8. doi: 10.1002/ccd.1810300220

3. Vorobcsuk A, Kónyi A, Aradi D, et al. Transradial versus transfemoral percutaneous coronary intervention in acute myocardial infarction Systematic overview and meta-analysis. Am Heart J 2009 Nov; 158(5): 814-21. doi: 10.1016/j.ahj.2009.08.022

4. Bertrand OF, Rao SV, Pancholy S, et al. Transradial approach for coronary angiography and interventions: results of the first international transradial practice survey. JACC Cardiovasc Interv 2010; 3(10): 1022-1031. doi: 10.1016/j.jcin.2010.07.013

5. Kim JY, Moon KW, Yoo KD, et al. Entrapment of a kinked catheter in the radial artery during transradial coronary angiography. J Invasive Cardiol 2012 Jan; 24(1): E3-4.

6. Waked A, Khoueiry G, Bhat T, et al. Entrapment of a looped/kinked catheter in the brachial artery and its successful retrieval during transradial coronary catheterization. J Invasive Cardiol 2012 Sep; 24(9): 471-2.

7. Aminian A, Fraser DG, Dolatabadi D, et al. Severe catheter kinking and entrapment during transradial coronary angiography: percutaneous retrieval using a sheathless guide catheter. Catheter Cardiovasc Interv 2015 Jan 1; 85(1): 91-4. doi: 10.1002/ccd.25515 